\title{
Correction: Cancer-associated fibroblasts promote progression and gemcitabine resistance via the SDF-1/SATB-1 pathway in pancreatic cancer
}

Lusheng Wei, Huilin Ye, Guolin Li, Yuanting Lu, Quanbo Zhou, Shangyou Zheng, Qing Lin, Yimin Liu, Zhihua Li and Rufu Chen

Correction to: Cell Death \& Disease

https://doi.org/10.1038/s41419-018-1104-x

published online 18 October 2018

Since online publication of this article, the authors noticed errors in Figs. 6C and 9A. In 6C an incorrect image was used for the primary image of "CAF-P4 FAP".
In Fig. 9A, incorrect brightness and scale were used for the SDF-1 'Low' and 'High' images, respectively. The authors apologise for these errors. The corrected images are provided below.

Published online: 03 March 2021
A

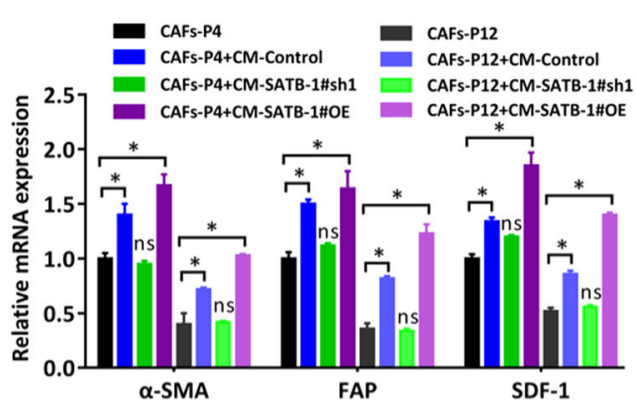

C

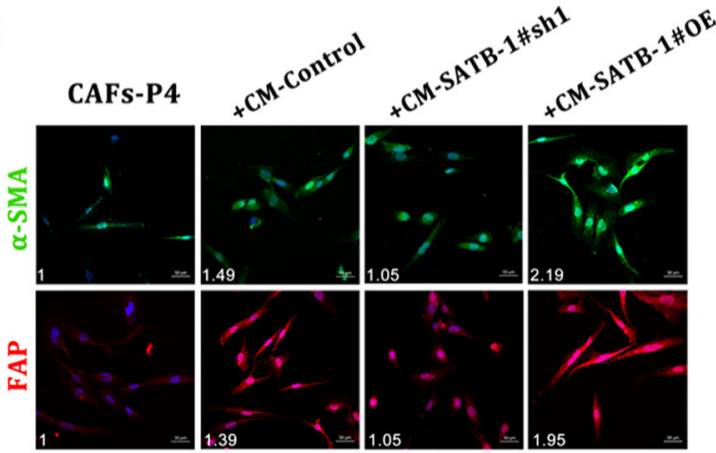

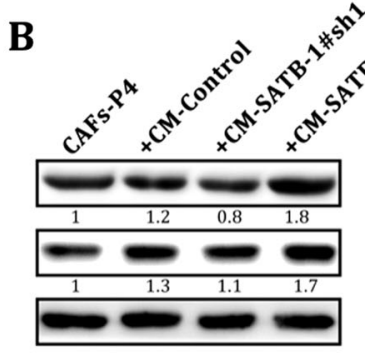
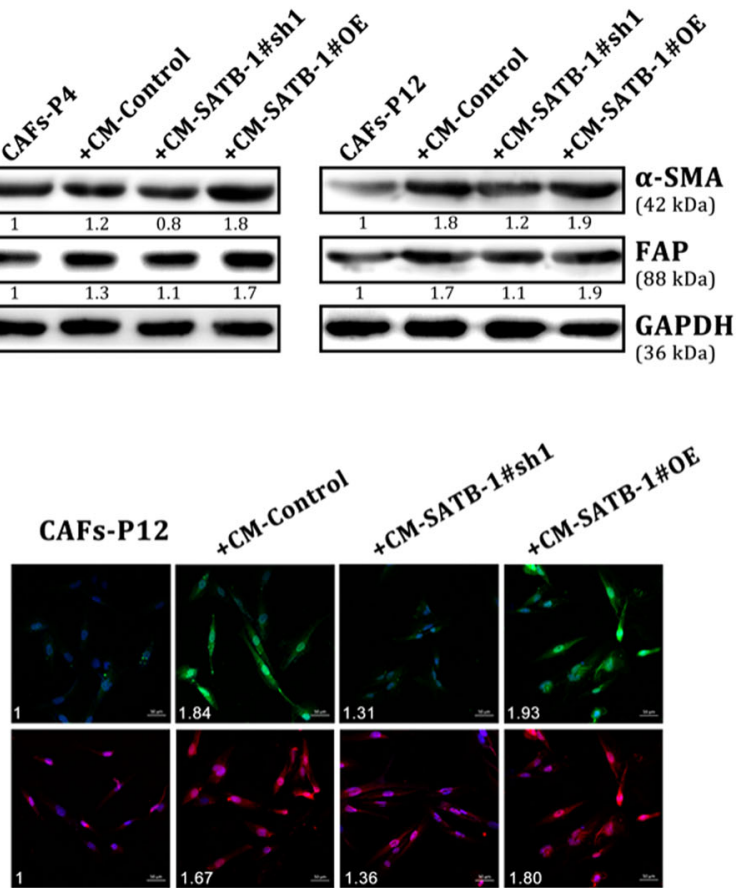

Fig. 6.

(c) (i) Open Access This article is licensed under a Creative Commons Attribution 4.0 International License, which permits use, sharing, adaptation, distribution and reproduction in any medium or format, as long as you give appropriate credit to the original author(s) and the source, provide a link to the Creative Commons license, and indicate if changes were made. The images or other third party material in this article are included in the article's Creative Commons license, unless indicated otherwise in a credit line to the material. If material is not included in the article's Creative Commons license and your intended use is not permitted by statutory regulation or exceeds the permitted use, you will need to obtain permission directly from the copyright holder. To view a copy of this license, visit http://creativecommons.org/licenses/by/4.0/. 


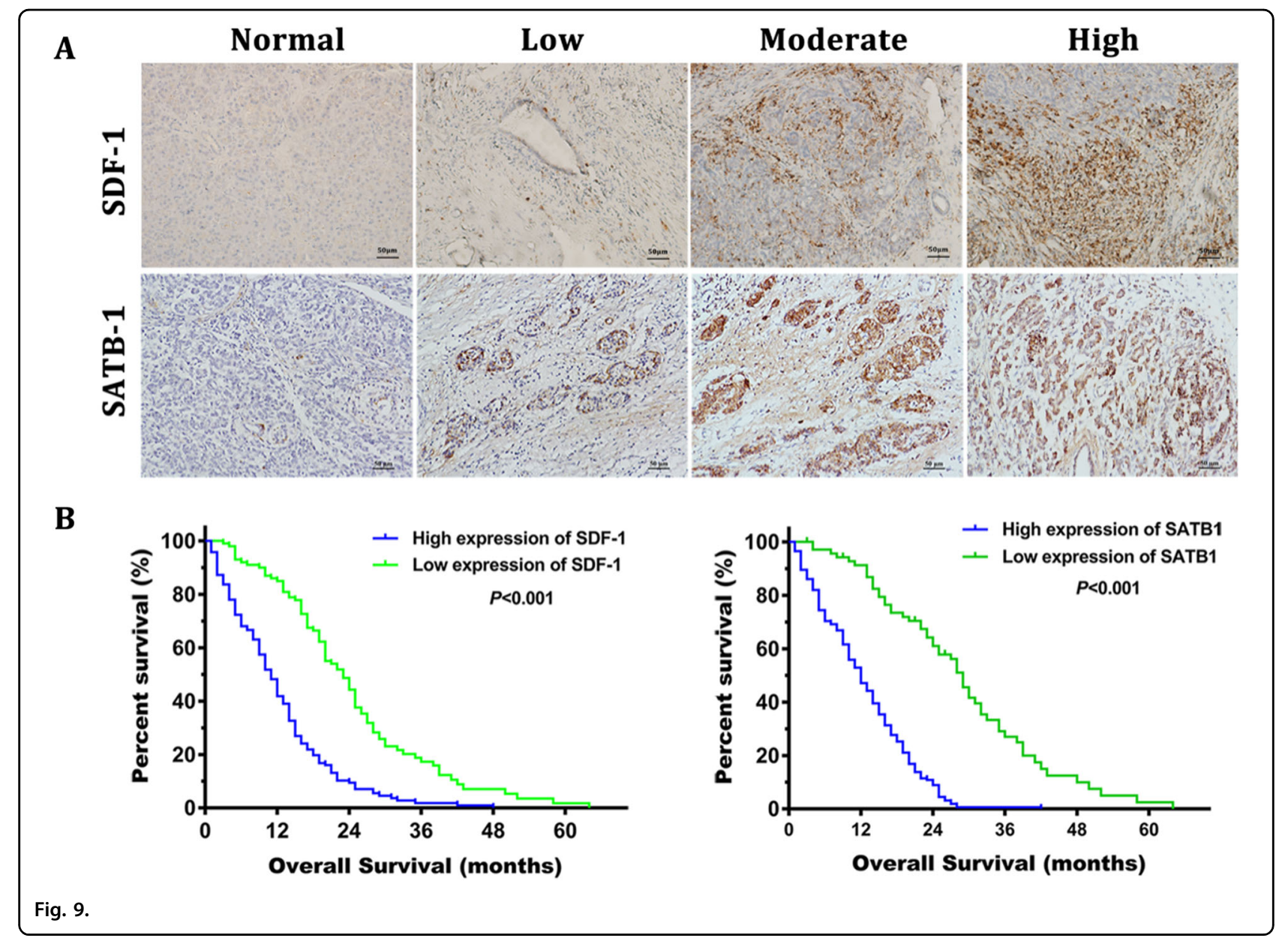

